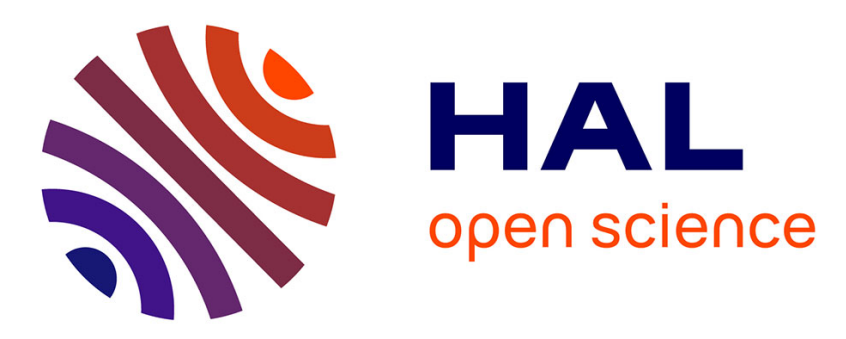

\title{
Modelling of the sulfuric acid attack on different types of cementitious materials
}

\author{
Anaïs Grandclerc, Patrick Dangla, Marielle Gueguen Minerbe, Thierry
}

Chaussadent

\section{- To cite this version:}

Anaïs Grandclerc, Patrick Dangla, Marielle Gueguen Minerbe, Thierry Chaussadent. Modelling of the sulfuric acid attack on different types of cementitious materials. Cement and Concrete Research, 2018, 105, 67 p. 10.1016/j.cemconres.2018.01.014 . hal-01880755

\section{HAL Id: hal-01880755 \\ https://hal.science/hal-01880755}

Submitted on 25 Sep 2018

HAL is a multi-disciplinary open access archive for the deposit and dissemination of scientific research documents, whether they are published or not. The documents may come from teaching and research institutions in France or abroad, or from public or private research centers.
L'archive ouverte pluridisciplinaire $\mathbf{H A L}$, est destinée au dépôt et à la diffusion de documents scientifiques de niveau recherche, publiés ou non, émanant des établissements d'enseignement et de recherche français ou étrangers, des laboratoires publics ou privés. 
Grandclerc A., Dangla P., Gueguen-Minerbe M., Chaussadent T., Modelling of the sulphuric acid attack on differents types of cementitious materials, Cement and Concrete Research 105 (2018) 126133

Modelling of the sulfuric acid attack on different types of cementitious materials GRANDCLERC Anaïs ${ }^{a^{*}}$, DANGLA Patrick ${ }^{\mathrm{b}}$, GUEGUEN-MINERBE Marielle ${ }^{\mathrm{a}}$ and CHAUSSADENT Thierry ${ }^{a}$

${ }^{a}$ Université Paris-Est, MAST, CPDM, IFSTTAR, F- 77447 Marne-la-Vallée, France

${ }^{\mathrm{b}}$ Université Paris-Est, Laboratoire Navier (UMR 8205), CNRS, École des Ponts ParisTech, F-77455 Marne-La-Vallée, France

*anais.grandclerc@ifsttar.fr

\section{Abstract}

A chemical-reactive transport model was used to simulate the sulfuric acid attack of cement pastes based on ordinary Portland cement (CEM I), blended Portland cements (CEM III, CEM IV, and CEM V), and calcium aluminate cement (CAC). This model accounts for the dissolution of cement hydrates (portlandite, C-S-H, hydrogarnet), and the precipitation of deterioration products (ettringite and gypsum). Moreover, diffusion of the aqueous species in the pore space in the material is considered. With this model, we can get the hydrate contents, the porosity, and the deterioration phase contents throughout a sulfuric acid attack. Two indicators are defined to predict the service life of the cementitious materials: the deterioration depth and the dissolved calcium content. These two indicators showed that calcium aluminate cement provide a better resistance to sulfuric acid attack than that of Portland cements. This better resistance is mainly due to the partial dissolution of CAC hydrate as opposed to the total dissolutions of $\mathrm{CH}$ and C-S-H.

Keywords: Deterioration (C.), Calcium Aluminate Cement (D.), Portland cement (D.), Modelling (E.), Acid attack

\section{Introduction}

Concrete can undergo severe deteriorations in sewer pipe conditions, caused by gaseous hydrogen sulphide (Figure 1) [1, 2]. Concrete gravity sewers are divided into two parts: a liquid part and an aerial part (sewer atmosphere). The liquid part contains waste water which is composed of sulfate ions and sulfate reducing bacteria (SRB). The cementitious wall in the aerial part is covered by a biofilm mainly 
Grandclerc A., Dangla P., Gueguen-Minerbe M., Chaussadent T., Modelling of the sulphuric acid attack on differents types of cementitious materials, Cement and Concrete Research 105 (2018) 126133

composed of sulphur-oxidizing bacteria (SOB). Aqueous hydrogen sulfide is produced in the anaerobic zone (waste water stagnation) from the reduction reaction of sulfate ions due to sulfate reducing bacteria. Then, $\mathrm{H}_{2} \mathrm{~S}$ escapes into the sewer atmosphere, where it is adsorbed onto the cementitious wall [3]. Due to the high relative humidity at the surface of the wall, gaseous hydrogen sulphide dissociates into hydrogen ions and sulfide ions. Hydrogen ions contribute to surface $\mathrm{pH}$ neutralization, giving rise to the biofilm development [4]. Under such aerobic conditions, sulfide ions oxidize into several sulphur species, which are used as nutrients for the microorganisms of the biofilm. Sulfuric acid is produced by the oxidation reactions of these sulphur species $[5,6]$. This acid attacks the cementitious walls and produces gypsum and ettringite $[7,8]$, which are expansive and cause severe damage of the sewer system. The sulfuric acid produced by these microorganisms diffuses through the altered layer and continually attacks the underlying concrete [9].

Numerical models of acid attack of cementitious materials [10-17] can be found in the literature. One of these models simulating the biochemical process and the sulfide oxidation is named "Wastewater Aerobic/anaerobic Transformations in Sewer" (WATS) [10, 11]. Another study [12] simulates sulfuric acid attack with a diffusion-reaction based model with a moving boundary to predict the corrosion rate. A reactive-transport model (HYTEC [13]; [14]) was also used to simulate the attack of cementitious materials by different types of organic acids. This model takes into account chemical interactions between these different organic acids and hydrates of cementitious materials based on Portland cement. Another model [15] has been proposed to simulate the acid attack of OPC and is based on the HYTEC model [14]. In this model, the dissolution of the main hydrates of the cementitious materials and the precipitation of deterioration products are simulated, using chemical equilibrium associated with thermodynamic constants and the transport of different species during sulfuric acid attack.

Some experimental studies $[9,18-21]$ in the literature have focused only on sulfuric acid attack of cementitious materials. For cementitious materials based on Portland cement, Bassuoni et al. [18] observed the dissolution of portlandite and the decalcification of C-S-H, which are the main hydrates of Portland cement, leading to mass loss. Kawai et al. [19] showed that cementitious materials containing 
Grandclerc A., Dangla P., Gueguen-Minerbe M., Chaussadent T., Modelling of the sulphuric acid attack on differents types of cementitious materials, Cement and Concrete Research 105 (2018) 126133

a high amount of silica fume have a better resistance than those containing fly ash or blast furnace slag. Jiang et al. [21] determined deterioration product localizations during these chemical reactions. Gypsum is the first product formed from the reaction between hydrates and sulfuric acid followed by ettringite localized near the undeteriorated concrete. Thermodynamically, ettringite is stable at $\mathrm{pH}$ greater than 10.7 [22] and forms only for high $\mathrm{pH}$ conditions. All these tests were performed on cementitious materials based on Portland cement or blended Portland cements. Several in-situ experiments (with microorganism presence) carried out by Alexander and Fourie [8] and Herisson et al. [23] suggested that cementitious materials based on calcium aluminate cement (CAC) have a better resistance than that of ordinary or blended Portland cements. Moreover, several laboratory tests of biodeterioration also showed better resistance for CAC materials [24-27].

In the present research, the behavior of cementitious materials based on different types of cement in contact with sulfuric acid was simulated with a predictive model based on the model of Yuan et al. [15]. The cements were ordinary Portland cement (CEM I), blended Portland cements (CEM III, CEM IV, and CEM V), and calcium aluminate cement (CAC). The aim of this study was to predict deterioration depth of cement subjected to sulfuric acid attack and to determine which one has a better resistance to this kind of corrosion. In this study, the biological acid production, depending on numerous parameters, is not modeled. Instead, it is assumed that, due to a lack of data concerning interaction of microorganisms and cementitious materials and its consequence on acid production, the considered hypothesis is that microorganisms produce sulfuric acid in such a way that sulfuric acid concentration is constant. This model is then static. Despite of this hypothesis, the model results obtained may be compared with those from experimental in-situ and laboratory tests for which microorganism activity can be dependent on environmental and material parameters.

\section{Hydrate composition of cements}

The cementitious materials considered were cement pastes with a water to cement ratio of 0.4 . The hydrate compositions and contents are presented in Table 1 and expressed in mole per liter of cement 
Grandclerc A., Dangla P., Gueguen-Minerbe M., Chaussadent T., Modelling of the sulphuric acid attack on differents types of cementitious materials, Cement and Concrete Research 105 (2018) 126133

paste. Initial data used for the model are porosity and hydrate amounts for each type of cement. For cement pastes based on CEM I, CEM III, CEM IV, and CEM V cements, the main hydrates are calcium silicate hydrate (C-S-H) and portlandite $(\mathrm{CH})$ and for cement pastes based on calcium aluminate cement, the main hydrates are hydrogarnet $\left(\mathrm{C}_{3} \mathrm{AH}_{6}\right)$ and gibbsite $\left(\mathrm{AH}_{3}\right)$. The chosen porosities are those of mortars, even if in the model, the cementitious materials considered are cement pastes. This consideration allows comparing model results (diffusion-controlled model leading to a high effect of the porosity) and experimental results.

Hydrate amounts were experimentally measured by TGA and Rietveld XRD techniques and the porosities were measured by the water absorption method [28]. The portlandite contents for CEM III, CEM IV, and CEM V cements are lower than that for CEM I cement, because the clinker is substituted by other compounds: blast furnace slag for CEM III cement, natural pozzolans for CEM IV cement, and a combination of blast furnace slag and fly ash for CEM V cement. In this model, the other phases of blended Portland cements (hydrates from the additions and anhydrous phases) were not taken into account in the chemical processes and the differences between the Portland cements are only controlled by the portlandite and C-S-H contents and the porosity.

With the purpose of comparing the behavior of cement pastes, the same calcium content is considered for all the cement, namely $6 \mathrm{~mol} / \mathrm{L}$. The C-S-H content is then deduced from a calcium to silicon ratio equal to 1.7 and the $\mathrm{CH}$ content. This assumption which may not reflect the reality, was considered with the aim of giving the same potential of calcium dissolution to all materials. Indeed, it is clear that the more the calcium content the better the resistance to calcium dissolution.

For the CAC materials, there are four main hydrates: $\mathrm{C}_{3} \mathrm{AH}_{6}, \mathrm{AH}_{3}, \mathrm{C}_{2} \mathrm{AH}_{8}$, and $\mathrm{CAH}_{10}$. If CAC paste undergoes heat treatment during the hydration mechanisms, the major hydrate is the stable hydrogarnet $\left(\mathrm{C}_{3} \mathrm{AH}_{6}\right)$ but if the hydration mechanisms take place at room temperature, the major hydrates formed are two metastable phases $\left(\mathrm{CAH}_{10}\right.$ and $\left.\mathrm{C}_{2} \mathrm{AH}_{8}\right) \cdot \mathrm{AH}_{3}$ (gibbsite) is formed in both cases. During heat treatment, the conversion reaction provokes the transformation from metastable hydrate to the stable hydrate. The conversion reactions are partial and begin from a curing temperature of $28^{\circ} \mathrm{C}$, reaching a 
Grandclerc A., Dangla P., Gueguen-Minerbe M., Chaussadent T., Modelling of the sulphuric acid attack on differents types of cementitious materials, Cement and Concrete Research 105 (2018) 126133

conversion rate of $100 \%$ for a temperature of $60^{\circ} \mathrm{C}$ [29]. For the model, only a CAC paste with $\mathrm{C}_{3} \mathrm{AH}_{6}$ as the main hydrate is considered. Lamberet et al. [30] indicate that the gibbsite $\left(\mathrm{AH}_{3}\right)$ is stable for a surface $\mathrm{pH}$ of the cementitious material between 4 and 11 . The CAC cement paste simulated in this study has a surface $\mathrm{pH}$ of 12 in the initial state. Therefore, gibbsite is not present initially. This hydrate can precipitate when the cementitious material is carbonated, inducing a surface $\mathrm{pH}$ around 7-8. However, the carbonation is not considered in this study and so the initial content is taken to zero (Table $1)$.

\section{Modelling of the $\mathrm{H}_{2} \mathrm{SO}_{4}$ attack of concrete}

\subsection{Chemical reactions and thermodynamic constants}

The reactive-transport model presented in Yuan et al. [15] takes into account the dissolution of $\mathrm{CH}$ and C-S-H and the precipitation of gypsum, so only the phase diagrams of the systems $\mathrm{CaO}-\mathrm{SiO}_{2}-\mathrm{H}_{2} \mathrm{O}$ and $\mathrm{CaO}-\mathrm{SO}_{3}-\mathrm{H}_{2} \mathrm{O}$ were considered. Alkali ions were also included in the system. In the present study, the model was improved by considering the system $\mathrm{CaO}-\mathrm{Al}_{2} \mathrm{O}_{3}-\mathrm{SO}_{3}-\mathrm{H}_{2} \mathrm{O}$, in addition to $\mathrm{CaO}-\mathrm{SiO}_{2}-\mathrm{H}_{2} \mathrm{O}$.

All the dissolution reactions implemented in the new model are listed in Table 2, for the heterogeneous reactions (in solid and aqueous phases) and in Table 3 for the homogeneous reactions (in only aqueous phase). The thermodynamic constant values are obtained from a data base (CEMDATA14.01). This system contains stable and metastable phases. For CAC materials, Damidot et al. [31] determined that the metastable phase AFm crystallizes only when $\mathrm{CAH}_{10}$ and $\mathrm{C}_{2} \mathrm{AH}_{8}$ are formed at $25^{\circ} \mathrm{C}$, whereas the stable phase AFt (ettringite) crystallizes only when $\mathrm{C}_{3} \mathrm{AH}_{6}$ is formed. As a result, in this system, $\mathrm{AFm}$ does not precipitate during the simulation.

\subsection{Stability of solid phases}

The stability of each solid phase can be described by the equality between the equilibrium constant (K) and the ion activity product $(\mathrm{Q})$. The ratio between $\mathrm{Q}$ and $\mathrm{K}$ defines the saturation index $\beta$. If $\beta$ is lower than unity, the solid phase would not precipitate and if $\beta$ is greater than unity, the solid phase would precipitate. For each solid phase, a saturation index is defined as a function of $\beta_{\mathrm{CH}}, \beta_{\mathrm{AH} 3}$, and $\mathrm{a}_{\mathrm{H} 2 \mathrm{SO} 4}$, 
Grandclerc A., Dangla P., Gueguen-Minerbe M., Chaussadent T., Modelling of the sulphuric acid attack on differents types of cementitious materials, Cement and Concrete Research 105 (2018) 126133

132

according to equations 1 to $6 . \beta_{\mathrm{CH}}, \beta_{\mathrm{AH} 3}$, and $\mathrm{a}_{\mathrm{H} 2 \mathrm{SO} 4}$ are respectively the saturation indexes of portlandite and gibbsite and the activity of $\mathrm{H}_{2} \mathrm{SO}_{4}$ (taken equal to $\mathrm{H}_{2} \mathrm{SO}_{4}$ concentration) and they are considered as primary variables. After the Gibbs phase rule, the system $\mathrm{CaO}-\mathrm{SO}_{3}-\mathrm{Al}_{2} \mathrm{O}_{3}-\mathrm{H}_{2} \mathrm{O}$ has 3 degrees of freedom at the most (at constant pressure and temperature), namely $\beta_{\mathrm{CH}}, \beta_{\mathrm{AH} 3}$, and $\mathrm{a}_{\mathrm{H} 2 \mathrm{SO} 4}$. The other saturation indexes can be derived from the mass action law under the form:

$\beta_{C S H 2}=10^{31.4} \beta_{C H} a_{H 2 S O 4}$

$\beta_{C 3 A H 6}=10^{4.59} \beta_{C H}^{3} \beta_{A H 3}^{2}$

$\beta_{C A H 10}=10^{-0.22} \beta_{C H} \beta_{A H 3}^{2}$

$\beta_{C 2 A H 8}=10^{67.4} \beta_{C H}^{2} \beta_{A H 3}^{2}$

$\beta_{A F m}=10^{38.4} a_{H 2 S O 4} \beta_{C H}^{4} \beta_{A H 3}^{2}$

$\beta_{A F t}=10^{107.5} \beta_{C H}^{6} \beta_{A H 3}^{2} a_{H 2 S O 4}^{3}$

From equations 1 to 6 , the stability zones of each solid phase included in this system are plotted in the phase diagram (Figure 2).

The continuous decalcification of C-S-H, during acid attack, is simulated in the present study by a thermodynamic approach presented in [32].

\subsection{Kinetic law}

Portlandite, $\mathrm{AH}_{3}$, and C-S-H are assumed in equilibrium with the solution. Dissolution and precipitation rates for $\mathrm{C}_{3} \mathrm{AH}_{6}$, gypsum, ettringite, and $\mathrm{AFm}$ are governed by a simple kinetic law (Equation 7).

$d n_{A} / d t=R_{A}\left(\beta_{A}-1\right)$

In Eq. (7), $\mathrm{n}_{\mathrm{A}}$ is the amount of solid $\mathrm{A}$ in $\mathrm{mol} / \mathrm{L}, \mathrm{R}_{\mathrm{A}}$ is the kinetic factor of the solid $\mathrm{A}$ in $\mathrm{mol} / \mathrm{L} / \mathrm{s}$ and $\beta_{\mathrm{A}}$ is the saturation index of the solid A. 
Grandclerc A., Dangla P., Gueguen-Minerbe M., Chaussadent T., Modelling of the sulphuric acid attack on differents types of cementitious materials, Cement and Concrete Research 105 (2018) 126133

The kinetic factors introduced in this law ( $\mathrm{R}_{\mathrm{C} 3 \mathrm{AH} 6}, \mathrm{R}_{\mathrm{AFt}}, \mathrm{R}_{\mathrm{AFm}}$, and $\mathrm{R}_{\mathrm{gypsum}}$ ) are adjusted so that equilibrium is quickly reached. Indeed, this kinetic law is governed by interface reactions. But, interface reactions are quicker than diffusion of aqueous species in the porous system in cementitious materials. As a result, the kinetic factors should be fixed as high as possible value, so as to get a saturation index as close as possible to 1 . But, the model does not converge with too big kinetic factors, so some simulation tests are performed by increasing the factors as high as possible. The values chosen are presented in Table 4.

\subsection{Porosity change}

During the chemical reactions, the change in porosity $(\Delta \phi)$ is given by the volume change of the solid phases $\left(\Delta \mathrm{V}_{\text {solid }}\right)$ according to equations 8 and 9.

$\Delta \phi=-\Delta V_{\text {solid }}$

Where $V_{\text {solid }}=\sum_{i} V_{i} n_{i}$ with summation over all solids, $\mathrm{V}_{\mathrm{i}}$ is the molar volume of each solid phase of the cement paste in $\mathrm{L} / \mathrm{mol}$ and $\mathrm{n}_{\mathrm{i}}$ is the amount of each solid phase in $\mathrm{mol} / \mathrm{L}\left(\mathrm{CH}, \mathrm{C}-\mathrm{S}-\mathrm{H}, \mathrm{C}_{3} \mathrm{AH}_{6}, \mathrm{AH}_{3}\right.$, $\mathrm{C}_{2} \mathrm{AH}_{8}, \mathrm{CAH}_{10}, \mathrm{C} \overline{\mathrm{S}} \mathrm{H}_{2}, \mathrm{AFm}$, and $\left.\mathrm{AFt}\right)$.

The molar volume of C-S-H ( $\left.\mathrm{V}_{\mathrm{C}-\mathrm{S}-\mathrm{H}}\right)$ included in equation 9 is a function of the calcium to silicon ratio, according to [15].

$V_{C-S-H}(x)=\left(x / x_{0}\right) V_{C-S-H}^{0}+\left(1-x / x_{0}\right) V_{S H}$

Where $\mathrm{x}$ is the calcium to silicon ratio at a fixed time of sulfuric acid attack, $\mathrm{x}_{0}$ is the initial calcium to silicon ratio of the cement paste $(\mathrm{C} / \mathrm{S}=1.7), V_{C-S-H}^{0}$ and $\mathrm{V}_{\mathrm{SH}}$ are the molar volumes of C-S-H at the initial state $\left(78 \mathrm{~cm}^{3} / \mathrm{mol}\right.$ for $\left.\mathrm{C}_{1.7} \mathrm{SH}_{2.1}\right)$ and of silica gel $\left(29 \mathrm{~cm}^{3} / \mathrm{mol}\right)$.

\subsection{Reactive transport model}

The system is controlled by chemical equilibrium but also by the transport of aqueous species. The coupling between these two mechanisms is taken into account within the modelling platform Bil [33], 
Grandclerc A., Dangla P., Gueguen-Minerbe M., Chaussadent T., Modelling of the sulphuric acid

attack on differents types of cementitious materials, Cement and Concrete Research 105 (2018) 126133

based on the finite volume method. This coupling is treated with a mass balance equation (Equation 10), a global balance equation for the charge (Equation 11), and an equation for the electroneutrality to form an electroneutral pore solution (Equation 12). These equations are detailed in the study of Yuan et al. $[15]$.

$\partial n_{A} / \partial t=-\operatorname{div} \boldsymbol{w}_{\boldsymbol{A}}$

$\operatorname{div} \underline{i}=0$

$\sum_{i} z_{i} \rho_{i}=0$

Where $\underline{i}=\sum_{i} z_{i} \boldsymbol{w}_{\boldsymbol{i}}$ is the ionic current and $\mathrm{n}_{\mathrm{A}}$ is the mole content of element $\mathrm{A}$ in all phases per unit volume, $\mathbf{w}_{\mathbf{A}}$ is the molar flow vector of element $A$ in the liquid phase, $z_{i}$ is the ionic valence of $i, \mathbf{w}_{\mathbf{i}}$ is the molar flow of $i$, and $\rho_{i}$ is the concentration of $i$.

The transport of aqueous species is governed by the Nernst-Planck equation, previously detailed in the study of Yuan et al. [15]. According to Bazant-Najjar law [34], the evolution of the effective diffusion coefficient is:

$D_{p} / D_{0}=2.9 .10^{4} \cdot \exp (9.95 . \phi)$

$D_{p}$ is the effective diffusion coefficient of aqueous species in the porous materials, $D_{0}$ is the effective diffusion coefficient in bulk water and $\phi$ is the porosity of the system at the current time and defined by the equation 8 .

\subsection{Description of the simulations}

These one dimensional (1D) studies aim at simulating the chemical processes in sewer pipes made of different cement types (CEM I, CEM III, CEM IV, CEM V cements, and CAC). The simulations are conducted in 1D only. The $2 \mathrm{~cm}$ long sample is discretized in 200 elements (finite volume). The boundary surface represents the interface between the cementitious materials and the $\mathrm{H}_{2} \mathrm{SO}_{4}$ solution. The initial $\mathrm{H}_{2} \mathrm{SO}_{4}$ concentration in the pore solution of samples is set to $10^{-32} \mathrm{~mol} / \mathrm{L}$, a very small value 
Grandclerc A., Dangla P., Gueguen-Minerbe M., Chaussadent T., Modelling of the sulphuric acid attack on differents types of cementitious materials, Cement and Concrete Research 105 (2018) 126133

consistent with the stability of the cement hydrates. At the boundary surface, the $\mathrm{H}_{2} \mathrm{SO}_{4}$ concentration is set to $10^{-1} \mathrm{~mol} / \mathrm{L}$, in order to study the deteriorations in extreme conditions. The damage model caused by gypsum formation as modeled in [15] was not extended to CAC system because this is ettringite which is mainly formed in CAC. So, in order to compare the durability of cement pastes, the deterioration depth is introduced as the distance between the first point where the porosity exceeds the initial porosity and the boundary surface.

\section{Results and Discussion}

\subsection{Profiles of the solid content}

The initial data for each type of cementitious material are summarized in Tables 1 and 4 . All the results are simulated for one year with a $\mathrm{H}_{2} \mathrm{SO}_{4}$ concentration of $10^{-1} \mathrm{~mol} / \mathrm{L}$ at the boundary surface of the cement pastes. The calculated profiles of solid phase contents, of the calcium to silicon ratio for the Portland cements and of the porosity, are plotted in Figure 3.

\subsubsection{Profiles of the solid contents for ordinary or blended Portland cements}

As indicated in Figure 3, the initial amount of portlandite for CEM I, CEM III, CEM IV, and CEM V cements (Table 1), is completely dissolved into calcium and hydroxide ions at a distance of 2-3 mm (depending on cement type) from the boundary surface. The depth which corresponds to this total dissolution, defines the dissolution front of portlandite.

The calcium to silicon ratio, drops down to 0 at a depth equivalent to the dissolution front of portlandite and corresponds to the decalcification front of C-S-H. This total decalcification $(\mathrm{C} / \mathrm{S}=0)$ infers that $\mathrm{C}$ S-H turns into silica gel near the boundary surface.

These two dissolutions induce the presence of calcium ions at the common dissolution and decalcification fronts of portlandite and C-S-H, and these ions react with sulfate ions from sulfuric acid solution and form a gypsum layer. The thickness of the gypsum layer is $2.0 \mathrm{~mm}$ for CEM I and CEM V cements and $2.4 \mathrm{~mm}$ for CEM III and CEM IV cements. The gypsum content at the surface reaches around $6 \mathrm{~mol} / \mathrm{L}$ for all the Portland cements. Moreover, ettringite in ordinary or blended Portland 
Grandclerc A., Dangla P., Gueguen-Minerbe M., Chaussadent T., Modelling of the sulphuric acid

attack on differents types of cementitious materials, Cement and Concrete Research 105 (2018) 126133

cements is considered negligible. The detection of this phase is infrequent in experimental studies [2426].

For the ordinary and blended Portland cements, porosity is equal to the initial porosity of each cementitious material until reaching the corresponding depth to the dissolution and decalcification fronts of portlandite and C-S-H. Indeed, when the two hydrates start to dissolve, new porous space is created and is partially filled by the precipitation of gypsum, leading to a porosity increase near the boundary surface. This porosity increase shows that gypsum does not fill the total porosity and its swelling cannot provoke structural damages.

\subsubsection{Profiles of the solid contents for CAC cement}

A different behavior is observed for the calcium aluminate cement. The acid attack (Figure 3 ) leads to a partial dissolution of the hydrogarnet $\left(\mathrm{C}_{3} \mathrm{AH}_{6}\right)$. Indeed, the initial hydrogarnet amount is equal to $2 \mathrm{~mol} / \mathrm{L}$ and decreases to $1.75 \mathrm{~mol} / \mathrm{L}$, after 1 year of sulfuric acid attack. The hydrogarnet dissolution is slower than portlandite dissolution and C-S-H decalcification observed in Portland cements. Gypsum does not precipitate in this cementitious material, the saturation index being lower than 1 during the simulation whereas the gibbsite and ettringite precipitate. The ettringite precipitation is due to the reaction between calcium ions and aluminum ions from the partial dissolution of the hydrogarnet and sulfate ions from the sulfuric acid solution (the maximum amount reached is $1.8 .10^{-1} \mathrm{~mol} / \mathrm{L}$ ). This precipitation tends to clog up the pores of this cementitious material, with the porosity reaching a value close to zero $\left(10^{-10} \%\right)$ at the depth corresponding to the maximum amount of ettringite. When the $\mathrm{pH}$ of the system drops down below 10.7, ettringite starts to dissolve [22] and causes an increase of porosity which reaches at the boundary surface a value slightly greater than the initial porosity of the CAC (Table 1). The gibbsite forms near the boundary surface with a maximum content reaching $1.5 .10^{-1} \mathrm{~mol} / \mathrm{L}$. This solid phase fills pores but this precipitation does not compensate the voids created by the dissolution of ettringite (the molar volume of ettringite is $710 \mathrm{~cm}^{3} / \mathrm{mol}$, whereas that of gibbsite is $64 \mathrm{~cm}^{3} / \mathrm{mol}$ ), resulting in an increase of porosity. As shown in the phase diagram (Figure 2), gypsum is not stable in presence of hydrogarnet. This is why simulations don't find any gypsum. However, in some 
Grandclerc A., Dangla P., Gueguen-Minerbe M., Chaussadent T., Modelling of the sulphuric acid

attack on differents types of cementitious materials, Cement and Concrete Research 105 (2018) 126133

experimental studies [35], gypsum can be found in the near surface zones of CAC binders attacked by sulfuric acid.

Damage caused by the ettringite precipitation is not implemented in this study. Experimental studies $[20,21,36]$ have shown some degradations that were explained by the important expansion of ettringite precipitation (needle like crystals creating locally micro-cracking). In the present study, ettringite fills the porous space and prevents the sulfuric acid from penetrating into the cementitious material. This phase has then a protective function.

\subsection{Determination of the deterioration depth and of weight loss for different cementitious material types}

The porosity profiles over depth obtained after one year of acid attack are plotted in Figure 4. The deterioration depth reached after one year of acid attack and the evolution of this parameter over time for each cementitious material are respectively proposed in Table 5 and Figure 5.

The deterioration depths obtained for CEM I, CEM III, CEM IV, and CEM V cements (Figure 4) are deeper than that obtained for CAC materials. Specifically, the deterioration depth reached after 1 year of acid attack for the CAC material is 10 times lower than that for the ordinary or blended Portland cements (Table 5 and Figure 5). Therefore, the CAC cement paste is clearly the most sustainable cement in acid conditions. The low deterioration kinetic for CAC materials is observed in many experimental field and laboratory studies $[8,20,23,26,27,39,40]$. In the model, this delaying effect is then due to the better stability of hydrogarnet in acidic conditions than the portlandite and C-S-H and to the ettringite formation, which clogs up the porosity of the material.

Several studies showed that an increase of the porosity causes a decrease of the compressive strength $[37,38]$. The porosity increases from 11 to $22 \%$ for CEM I cement, from 14 to $25 \%$ for CEM III cement, from 16 to $26 \%$ for CEM IV cement and from 11 to $23 \%$ for CEM V cement, whereas the porosity increases from 10 to $13 \%$ for the CAC material. The ordinary or blended Portland cements undergo a 
Grandclerc A., Dangla P., Gueguen-Minerbe M., Chaussadent T., Modelling of the sulphuric acid

attack on differents types of cementitious materials, Cement and Concrete Research 105 (2018) 126133

comparable decrease of compressive strength and a more important decrease than that of CAC, highlighted the better resistance of CAC materials to acid attack.

Some differences are observed between Portland cements. The deterioration kinetic is quicker for CEM III and CEM IV cements than for CEM I and CEM V cements (Figure 5). These results are mainly due to the high porosity of CEM III and CEM IV cements as compared to the porosity of CEM I and CEM V cements (Table 1). But, these qualitative important differences between these Portland cements need to be confirmed. Indeed, other hydrates than C-S-H and portlandite for blended Portland cements or anhydrous phases were not taken into account in the model. Specifically, the phases from the hydration of blast furnace slag, natural pozzolans, and fly ashes, leading to C-A-S-H and C-S-H with different C/S ratio and anhydrous phases should be considered.

The dissolved calcium contents are determined for each cementitious material after 1 year of sulfuric acid attack and are presented in Table 6. This parameter is plotted over time (Figure 6) and allows characterizing cementitious materials deterioration, with data about the loss of matter during the acid attack.

The dissolved calcium content reached after 1 year of sulfuric acid attack for the Portland cements is more than two times greater than the value for the CAC material (Table 6), highlighting the partial dissolution of hydrogarnet and the total dissolutions of $\mathrm{CH}$ and C-S-H. The evolution of the dissolved calcium content is linear with $\sqrt{t}$ for CEM I, CEM III, CEM IV, and CEM V cements. For CAC cement, this parameter is almost linear with time. But, this evolution is considered as linear with $\sqrt{t}$ (the correlation coefficient is equal to 0.92 ), in order to compare the cementitious materials.

\subsection{Long-term prediction}

The deterioration depths obtained are only calculated over 1 year of sulfuric acid attack. Yuan et al. [15] considered the evolution of the deterioration depth over time as a linear function of the square root of time, i.e. $K \sqrt{t}$. The proportionality with the square root of time is characteristic of a diffusion process. 
Grandclerc A., Dangla P., Gueguen-Minerbe M., Chaussadent T., Modelling of the sulphuric acid

attack on differents types of cementitious materials, Cement and Concrete Research 105 (2018) 126133

The values of $\mathrm{K}$ for all cementitious materials are shown in Table 7 and are considered equal to deterioration rates.

The deterioration rate obtained for the CAC material is 10 times lower than the deterioration rates for the Portland cements (Table 7). The field tests from literature $[8,38,39]$ showed a corrosion rate 4 times lower for the CAC material in regard to CEM I cement. Consequently, this model overestimates the better resistance of CAC materials, but it qualitatively consistent with observations. Moreover, the aim of these simulations is to give chemical-based understanding of the better resistance of CAC cement already observed with in-situ or laboratory tests. The partial dissolution of hydrogarnet shows that this type of cement is constituted of hydrate resistant to acid conditions.

\section{Conclusion}

In this study, the effect of the cementitious material types on the deterioration obtained during 1 year of sulfuric acid attack is evaluated with a chemical-reactive transport model.

The main results of the modeling highlight that the deterioration kinetic of the CAC materials is slower than that of other cements (CEM I, CEM III, CEM IV and CEM V), as observed in several field tests. This better resistance is mainly explained by the better thermodynamic stability in acidic conditions of hydrogarnet compared to portlandite and C-S-H and to the ettringite precipitation which prevents the penetration of sulfuric acid with a pore-blocking effect. But, this better resistance needs to be qualified due to the ettringite precipitation, difficult to reconcile with some experimental studies.

The main perspectives for this sulfuric acid deterioration model are first, the implementation of a damage model for the gypsum swelling and the ettringite precipitation for all the cementitious materials studied. The second point to improve obviously concerns the consideration of the microorganisms which produce sulfuric acid in sewer networks. Indeed, the factors controlling bio receptivity of cementitious materials, which ultimately steers the acid production, are essential for modelling. Finally, the third point is the inclusion of additional phases for blended Portland cements (blast furnace slag, pozzolans, and fly ashes) in order to better represent these kinds of cements. 
Grandclerc A., Dangla P., Gueguen-Minerbe M., Chaussadent T., Modelling of the sulphuric acid

attack on differents types of cementitious materials, Cement and Concrete Research 105 (2018) 126133

\section{Acknowledgment}

This study was carried out in the frame of the FUI Duranet project and funded by BpiFrance (contract F1409022M).

\section{References}

[1]Brongers M., Koch G., Thompson N., Corrosion costs and preventive strategies in the United States, Report FHWA-RD-01-156, 2001, Federal Highway Administration, Washington, DC.

[2] Zhang L., De Schryver P., De Gusseme B., De Muynck W., Boon N. and Verstraete W., Chemical and biological technologies for hydrogen sulfide emission control in sewer systems: a review, Water Research 42 (2008): 1-12.

[3] Boon A.G., Specificity in sewers: causes, consequences and containments, Water Science Technology 31 (1995): 237-253.

[4] Joseph A.P., Keller J., Bustamante H. and Bond P.L., Surface neutralization and $\mathrm{H}_{2} \mathrm{~S}$ oxidation at early stages of sewer corrosion: Influence of temperature, relative humidity and $\mathrm{H}_{2} \mathrm{~S}$ concentration, Water Research 46 (2012): 4235-45.

[5] Islander R.L., Devinny J.S., Mansfeld F., Postyn A. and Shih H., Microbial ecology of crown corrosion in sewers, Journal of Environmental Engineering 117 (1991): 761-770.

[6] Okabe S., Odagiri M., Ito, T. and Satoh H., Succession of sulfur-oxidizing bacteria in the microbial community on corroding concrete in sewer systems, Applied and Environmental Microbiology 73 (2007): 971-80.

[7] Davis J.L., Nica D., Shields K. and Roberts D.J., Analysis of concrete from corroded sewer pipe, 
Grandclerc A., Dangla P., Gueguen-Minerbe M., Chaussadent T., Modelling of the sulphuric acid attack on differents types of cementitious materials, Cement and Concrete Research 105 (2018) 126133

International Biodeterioration \& Biodegradation 42 (1998): 75 - 84.

347

348

349

350

351

352

353

354

355

[8] Alexander M. G. and Fourie C., Performance of sewer pipe concrete mixtures with Portland and calcium aluminate cements subject to mineral and biogenic acid attack, Materials and Structures 44 (2010): 313-30.

[9] Pavlík V., Corrosion of hardened cement paste by acetic and nitric acids part I: Calculation of corrosion depth, Cement and Concrete Research 24 (1994): 551-62.

[10] Nielsen A.H., Hvitved-Jacobsen T. and Vollertsen J., Kinetics and stoichiometry of sulfide oxidation by sewer biofilms, Water Research 39 (2005): 4119-25.

[11] Jensen H.S., Nielsen A.H., Hvitved-Jacobsen T. and Vollertsen J., Modeling of hydrogen sulfide oxidation in concrete corrosion products from sewer pipes, Water Environment Research 81 (2009): 365-73.

[12] Jahani F., Devinny J., Mansfeld F., Rosen I.G., Sun Z. and Wang C., Investigations of sulfuric acid corrosion of concrete. II: electrochemical and visual observations, Journal of environmental engineering 127 (2001): 580-584.

[13] Van der Lee G., De Windt L., Lagneau V. and Goblet P., Module-oriented modeling of reactive transport with HYTEC, Computers \& Geosciences 29 (2003): 265-75.

[14] De Windt L. and Devillers P., Modeling the degradation of Portland cement pastes by biogenic organic acids, Cement and Concrete Research 40 (2010): 1165-74.

[15] Yuan H., Dangla P., Chatellier P. and Chaussadent T., Degradation modelling of concrete submitted to sulfuric acid attack, Cement and Concrete Research 53 (2013): 267-77.

[16] Chalupeckỳ, V., Fatima T., Kruschwitz J. and Muntean A., CASA-Report 12-01 January 2012.

[17] Yuan H., Dangla P., Chatellier P. and Chaussadent T., Degradation modeling of concrete submitted 
Grandclerc A., Dangla P., Gueguen-Minerbe M., Chaussadent T., Modelling of the sulphuric acid attack on differents types of cementitious materials, Cement and Concrete Research 105 (2018) 126133

368

369

370

371

372

373

374

375

376

377

378

379

380

381

382

383

384

385

386

387

388

389

390

to biogenic acid attack, Cement and Concrete Research 70 (2015): 29-38.

[18] Bassuoni M.T. and Nehdi M.L., Resistance of self-consolidating concrete to sulfuric acid attack with consecutive pH reduction, Cement and Concrete Research 37 (2007): 1070-84.

[19] Kawai K., Sako A., Ikuta T. and Ishida T., Deterioration of cement hydrates containing mineral admixtures due to sulfuric acid attack, In 11DBMC International Conference on Durability of Building Materials and Components, Istanbul, Turkey, 2008.

[20] Herisson J., Van Hullebusch E.D., Moletta-Denat M., Taquet P. and Chaussadent T., Toward an accelerated biodeterioration test to understand the behavior of Portland and Calcium Aluminate cementitious materials in sewer networks, International Biodeterioration \& Biodegradation 84 (2013): 236-43.

[21] Jiang G., Wightman E., Bogdan C. D., Yuan Z., Bond P.L. and Keller J., The role of iron in sulfide induced corrosion of sewer concrete, Water Research 49 (2014): 166-74.

[22] Gabrisova A., Havlica J. and Sahu S., Stability of calcium sulphoaluminate hydrates in water solutions with various pH values, Cement and Concrete Research 21 (1991): 1023-1027.

[23] Herisson J., Guéguen-Minerbe M., Van Hullebusch E.D. and Chaussadent T., Behaviour of different cementitious material formulations in sewer networks, Water Science \& Technology 69 (2014): 1502.

[24] Schmidt M., Hormann K. and Hofmann F., Stability of concrete against biogenic sulfuric acid corrosion, a new method for determination, In Proceedings of the 10th international congress on the chemistry of cement, Gothenburg, 1997.

[25] Ehrich S., Helard L., Letourneux R., Willocq J. and Bock E., Biogenic and chemical sulfuric acid corrosion of mortars, Journal of materials in civil engineering 11 (1999): 340-344.

[26] Miokono, D.H.E, Biodétérioration de mortiers avec une succéssion de bactéries sulfo-oxydantes 
Grandclerc A., Dangla P., Gueguen-Minerbe M., Chaussadent T., Modelling of the sulphuric acid attack on differents types of cementitious materials, Cement and Concrete Research 105 (2018) 126133

391

392

393

394

395

396

397

398

399

400

401

402

403

404

405

406

407

408

409

410

411

412

413

neutrophiles et acidophiles, PhD at the University of Lille 1, 2013, 365 pages.

[27] Peyre Lavigne M., Bertron A., Auer L., Hernandez-Raquet G., Foussard J.N., Escadeillas G., Cockx A. and Paul E., An innovative approach to reproduce the biodeterioration of industrial cementitious products in a sewer environment. Part I: Test design, Cement and Concrete Research 73 (2015): 24656.

[28] NF P18-459, “Concrete - Hardened concrete test - Porosity and density tests", French standard, 2010.

[29] Nilforushan M.R and Talebian N., The hydration products of a refractory calcium aluminate cement at intermediate temperatures, Iran. J. Chem. Eng 26 (2007).

[30] Lamberet S., Guinot D., Lempereur E., Talley J. and Alt C., Fields investigations of high performance calcium aluminate mortar for wastewater applications, Calcium aluminate cements, proceeeding of the centenary conference, Avignon, IHS BRE Press, 2008.

[31] Damidot D., Lothenbach B., Herfort D. and Glasser F.P., Thermodynamic and cement science, Cement and Concrete Research 41 (2011): 679-695.

[32] Dangla P., Thiery M. and Morandeau A., Thermodynamic of incongruent solubility of C-S-H, Advances in Cement Research (2015) (online version).

[33] Dangla P., Bil-2.4, A modeling platform based on finite volume/element method, doi: 10.5281/zenodo.1039729, 2017.

[34] Bazant Z.P. and Najjar L.J., Nonlinear water diffusion in nonsaturated concrete, Materials and structures 5(1972): 3-20.

[35] Proceedings of the RILEM TC-211-PAE, Performance of cement-based materials in aggressive aqueous environments, Springer (2013), ISBN 978-94-007-5419-3.

[36] Mori T., Nonaka M., Tazaki K., Koga M., Hikosaka Y. and Noda S., Interactions of nutrients, 
Grandclerc A., Dangla P., Gueguen-Minerbe M., Chaussadent T., Modelling of the sulphuric acid attack on differents types of cementitious materials, Cement and Concrete Research 105 (2018) 126133

414 moisture and $\mathrm{pH}$ on microbial corrosion of concrete sewer pipes, Water Research 26 (1991): 29-37.

415 [37] Lee H.S., Ismail M.A., Woo Y.J., Min T.B. and Choi H.C., Fundamental study on the development 416 of structural lightweight concrete by using normal coarse aggregate and foaming agent, Materials 7 417 (2014): 4536-4554.

418 [38] Zhao H., Xiao Q., Huang D. and Zhang S., Influence of pore structure on compressive strength of 419 cement mortar, Scientific World Journal, Article ID 247058, 2014.

420 [39] Goyns A., Calcium aluminate cement linings for cost-effective sewers, In International conference 421 on calcium aluminate cements, 6317-6319, 2001.

422 [40] Alexander M. G., Goyns A. and Fourie C.W., Experiences with a full-scale experimental sewer 423 made with CAC and other cementitious binders in Virginia, South Africa, In Proceedings, calcium 424 aluminate cements, the centenary conference. IHS BRE Press, Bracknell, 279-292, 2008. 
Grandclerc A., Dangla P., Gueguen-Minerbe M., Chaussadent T., Modelling of the sulphuric acid attack on differents types of cementitious materials, Cement and Concrete Research 105 (2018) 126133

\begin{tabular}{|c|c|c|c|c|c|}
\hline Cement & $\begin{array}{c}\mathbf{n}_{\mathbf{C H}} \\
(\mathbf{m o l} / \mathbf{L})\end{array}$ & $\begin{array}{c}\mathbf{n}_{\mathbf{C S H}} \\
(\mathbf{m o l} / \mathbf{L})\end{array}$ & $\begin{array}{c}\mathbf{n}_{\mathbf{C 3 A H} 6} \\
(\mathbf{m o l} / \mathbf{L})\end{array}$ & $\begin{array}{c}\mathbf{n}_{\text {AH3 }} \\
(\mathbf{m o l} / \mathbf{L})\end{array}$ & $\begin{array}{c}\text { Porosity } \\
(\mathbf{\%})\end{array}$ \\
\hline CEM I & 1.84 & 2.45 & - & - & 11 \\
\hline CEM III & 1.18 & 2.83 & - & - & 18 \\
\hline CEM IV & 0.75 & 3.10 & - & - & 16 \\
\hline CEM V & 1.19 & 2.84 & & & 11 \\
\hline CAC & - & - & 2 & 0 & 10 \\
\hline
\end{tabular}

Table 1: Hydrate amounts and porosity for cement pastes based on CEM I, CEM III, CEM IV, CEM V cements, and CAC.

\begin{tabular}{|c|c|c|}
\hline Solid phases & Dissolution reactions & $\begin{array}{l}\text { Thermodynamic } \\
\text { constant }(\mathrm{K})\end{array}$ \\
\hline Portlandite (CH) & $\begin{array}{l}\text { Reaction involving calcium compounds } \\
\qquad \mathrm{Ca}(\mathrm{OH})_{2} \leftrightharpoons \mathrm{Ca}^{2+}+2 \mathrm{OH}^{-}\end{array}$ & $8.90 .10^{-6}$ \\
\hline Gibbsite $\left(\mathrm{AH}_{3}\right)$ & $\begin{array}{c}\text { Reaction involving aluminum compounds } \\
\qquad \mathrm{Al}(\mathrm{OH})_{3}^{-} \leftrightharpoons \mathrm{Al}^{3+}+6 \mathrm{OH}^{-}\end{array}$ & $1.0 .10^{-68}$ \\
\hline Gypsum $\left(\mathbf{C} \bar{S} H_{2}\right)$ & $\begin{array}{l}\text { Reaction involving calcium-sulfur compounds } \\
\qquad \mathrm{CaSO}_{4} \cdot 2 \mathrm{H}_{2} \mathrm{O} \leftrightharpoons \mathrm{Ca}^{2+}+\mathrm{SO}_{4}^{2-}+2 \mathrm{H}_{2} \mathrm{O}\end{array}$ & $3.72 .10^{-5}$ \\
\hline Ettringite $\left(\mathrm{C}_{\mathbf{3}} \mathrm{A} \overline{\boldsymbol{S}}_{\mathbf{3}} \mathrm{H}_{32}\right)$ & $\begin{array}{c}\text { Reactions involving calcium-aluminum-sulfur } \\
\text { compounds } \\
3 \mathrm{CaO} . \mathrm{Al}_{2} \mathrm{O}_{3} \cdot \mathrm{CaSO}_{4} \cdot 12 \mathrm{H}_{2} \mathrm{O} \leftrightharpoons 4 \mathrm{Ca}^{2+}+2 \mathrm{Al}(\mathrm{OH})_{4}^{-}+4 \mathrm{OH}^{-} \\
+\mathrm{SO}_{4}{ }^{2-}+6 \mathrm{H}_{2} \mathrm{O} \\
3 \mathrm{CaO} . \mathrm{Al}_{2} \mathrm{O}_{3} \cdot 3 \mathrm{CaSO}_{4} \cdot 32 \mathrm{H}_{2} \mathrm{O} \leftrightharpoons 6 \mathrm{Ca}^{2+}+2 \mathrm{Al}(\mathrm{OH})_{4}^{-}+ \\
3 \mathrm{SO}_{4}{ }^{2-}+4 \mathrm{OH}^{-}+26 \mathrm{H}_{2} \mathrm{O}\end{array}$ & $3.71 .10^{-30}$ \\
\hline $\begin{array}{l}\text { Hydrogarnet } \\
\left(\mathrm{C}_{3} \mathrm{AH}_{6}\right)\end{array}$ & $\begin{array}{c}\text { Reactions involving calcium-aluminum compounds } \\
3 \mathrm{CaO} \cdot \mathrm{Al}_{2} \mathrm{O}_{3} \cdot 6 \mathrm{H}_{2} \mathrm{O} \leftrightharpoons 3 \mathrm{Ca}^{2+}+2 \mathrm{Al}(\mathrm{OH})_{4}^{-}+4 \mathrm{OH}^{-}\end{array}$ & $3.2 .10^{-21}$ \\
\hline $\mathrm{C}_{2} \mathrm{AH}_{8}$ & $2 \mathrm{CaO} . \mathrm{Al}_{2} \mathrm{O}_{3} .8 \mathrm{H}_{2} \mathrm{O} \leftrightharpoons 2 \mathrm{Al}(\mathrm{OH})_{4}^{-}+2 \mathrm{Ca}^{2+}+3 \mathrm{H}_{2} \mathrm{O}+2 \mathrm{OH}^{-}$ & $2.8 .10^{-14}$ \\
\hline $\mathrm{CAH}_{10}$ & $\mathrm{CaO} \cdot \mathrm{Al}_{2} \mathrm{O}_{3} \cdot 10 \mathrm{H}_{2} \mathrm{O} \leftrightharpoons 2 \mathrm{Al}(\mathrm{OH})_{4}^{-}+\mathrm{Ca}^{2+}+6 \mathrm{H}_{2} \mathrm{O}$ & $2.5 .10^{-8}$ \\
\hline C-S-H & $\begin{array}{c}\text { Reaction involving calcium-silicon compounds } \\
\mathrm{C}_{\mathrm{x}} \mathrm{S}_{\mathrm{y}} \mathrm{H}_{\mathrm{z}} \leftrightharpoons \mathrm{xCa}^{2+}+2 \mathrm{xOH}^{-}+\mathrm{ySiO}_{2}^{0}+(\mathrm{z}-\mathrm{x}) \mathrm{H}_{2} \mathrm{O}\end{array}$ & See $[15]$ \\
\hline Silica gel (SH) & $\begin{array}{l}\text { Reaction involving silicon compounds } \\
\qquad \mathrm{SH}_{\mathrm{u}} \leftrightharpoons \mathrm{SiO}_{2}{ }^{0}+\mathrm{uH}_{2} \mathrm{O}\end{array}$ & $1.74 .10^{-3}$ \\
\hline
\end{tabular}

Table 2: Heterogeneous reactions taking place in the $\mathrm{CaO}-\mathrm{Al}_{2} \mathrm{O}_{3}-\mathrm{SiO}_{2}-\mathrm{SO}_{3}-\mathrm{H}_{2} \mathrm{O}$ system 
Grandclerc A., Dangla P., Gueguen-Minerbe M., Chaussadent T., Modelling of the sulphuric acid attack on differents types of cementitious materials, Cement and Concrete Research 105 (2018) 126133

\begin{tabular}{|c|c|}
\hline Dissociation reactions & $\begin{array}{l}\text { Thermodynamic } \\
\text { constant }(\mathrm{K})\end{array}$ \\
\hline $\begin{array}{l}\text { Reaction involving calcium compounds } \\
\qquad \begin{array}{c}\mathrm{Ca}(\mathrm{OH})_{2}{ }^{0} \leftrightharpoons \mathrm{Ca}^{2+}+2 \mathrm{OH}^{-} \\
\mathrm{Ca}(\mathrm{OH})^{+} \leftrightharpoons \mathrm{Ca}^{2+}+\mathrm{OH}^{-}\end{array}\end{array}$ & $\begin{array}{c}1 \\
1.66 .10^{1}\end{array}$ \\
\hline $\begin{array}{c}\text { Reactions involving silicon compounds } \\
\mathrm{SiO}_{2}{ }^{0}+2 \mathrm{H}_{2} \mathrm{O} \leftrightharpoons \mathrm{H}_{4} \mathrm{SiO}_{4}{ }^{0} \\
\mathrm{H}_{4} \mathrm{SiO}_{4}{ }^{0} \leftrightharpoons \mathrm{H}_{3} \mathrm{SiO}_{4}{ }^{-}+\mathrm{H}^{+} \\
\mathrm{H}_{3} \mathrm{SiO}_{4}{ }^{-} \leftrightharpoons \mathrm{H}_{2} \mathrm{SiO}_{4}{ }^{2-}+\mathrm{H}^{+} \\
\mathrm{H}_{2} \mathrm{SiO}_{4}{ }^{2-} \leftrightharpoons \mathrm{HSiO}_{4}{ }^{3-}+\mathrm{H}^{+}\end{array}$ & $\begin{array}{l}1.94 .10^{-3} \\
1.55 .10^{-10} \\
4.68 .10^{-14} \\
1.0 .10^{-15}\end{array}$ \\
\hline $\begin{array}{l}\text { Reaction involving sodium compounds } \\
\qquad \mathrm{NaOH}^{0} \leftrightharpoons \mathrm{Na}^{+}+\mathrm{OH}^{-}\end{array}$ & 1.5 \\
\hline $\begin{array}{l}\text { Reaction involving potassium compounds } \\
\qquad \mathrm{KOH}^{0} \leftrightharpoons \mathrm{K}^{+}+\mathrm{OH}^{-}\end{array}$ & 2.9 \\
\hline $\begin{array}{c}\text { Reactions involving sulfur compounds } \\
\mathrm{H}_{2} \mathrm{SO}_{4}{ }^{0} \leftrightharpoons \mathrm{HSO}_{4}^{-}+\mathrm{H}^{+} \\
\mathrm{HSO}_{4}{ }^{-} \leftrightharpoons \mathrm{SO}_{4}{ }^{2-}+\mathrm{H}^{+}\end{array}$ & $\begin{array}{l}1.0 .10^{6} \\
1.0 .10^{-2}\end{array}$ \\
\hline $\begin{array}{l}\text { Reaction involving aluminum compounds } \\
\qquad \mathrm{Al}(\mathrm{OH})_{4}^{-} \leftrightharpoons \mathrm{Al}^{3+}+4 \mathrm{OH}^{-}\end{array}$ & $6.2 .10^{-34}$ \\
\hline $\begin{array}{l}\text { Reactions involving calcium-silicon compounds } \\
\qquad \begin{array}{c}\mathrm{CaH}_{2} \mathrm{SiO}_{4}{ }^{0} \leftrightharpoons \mathrm{Ca}^{2+}+\mathrm{H}_{2} \mathrm{SiO}_{4}{ }^{2-} \\
\mathrm{CaH}_{3} \mathrm{SiO}_{4}{ }^{+} \leftrightharpoons \mathrm{Ca}^{2+}+\mathrm{H}_{3} \mathrm{SiO}_{4}^{-}\end{array}\end{array}$ & $\begin{array}{l}3.89 .10^{4} \\
1.56 .10^{1} \\
\end{array}$ \\
\hline $\begin{array}{c}\text { Reaction involving calcium-sulfur compounds } \\
\mathrm{Ca}^{2+}+\mathrm{SO}_{4}{ }^{2-} \leftrightharpoons \mathrm{CaSO}_{4}{ }^{0} \\
\mathrm{Ca}^{2+}+\mathrm{HSO}_{4} \leftrightharpoons \mathrm{CaHSO}_{4}{ }^{+}\end{array}$ & $\begin{array}{l}1.4 .10^{-3} \\
1.3 .10^{1}\end{array}$ \\
\hline
\end{tabular}

Table 3: Homogeneous aqueous reactions taking place in $\mathrm{CaO}-\mathrm{Al}_{2} \mathrm{O}_{3}-\mathrm{SiO}_{2}-\mathrm{SO}_{3}-\mathrm{Na}_{2} \mathrm{O}-\mathrm{K}_{2} \mathrm{O}-\mathrm{H}_{2} \mathrm{O}$ system

\begin{tabular}{|c|c|c|}
\hline Solid phases & $\begin{array}{c}\mathbf{R}_{\mathbf{A}}(\mathbf{m o l} / \mathbf{L} / \mathbf{s}) \\
\text { for Portland cements }\end{array}$ & $\begin{array}{c}\mathbf{R}_{\mathbf{A}}(\mathbf{m o l} / \mathbf{L} / \mathbf{s}) \text { for } \mathbf{C A C} \\
\text { cement }\end{array}$ \\
\hline $\mathrm{C} \overline{\mathrm{S}} \mathrm{H}_{2}$ (gypsum) & $1.10^{-4}$ & $1.10^{-7}$ \\
\hline $\mathrm{AFt}$ & $1.10^{-11}$ & $1.10^{-7}$ \\
\hline $\mathrm{AFm}$ & $1.10^{-11}$ & $1.10^{-11}$ \\
\hline $\mathrm{C}_{3} \mathrm{AH}_{6}$ & - & $1.10^{-8}$ \\
\hline
\end{tabular}

Table 4: Kinetic factors of the solid phases for the $\mathrm{CaO}-\mathrm{Al}_{2} \mathrm{O}_{3}-\mathrm{SO}_{3}-\mathrm{H}_{2} \mathrm{O}$ system.

\begin{tabular}{|c|c|}
\hline Cement pastes & Deterioration depths (mm) \\
\hline CEM I & 2.0 \\
\hline CEM III & 2.4 \\
\hline CEM IV & 2.8 \\
\hline CEM V & 2.2 \\
\hline CAC & 0.2 \\
\hline
\end{tabular}


Grandclerc A., Dangla P., Gueguen-Minerbe M., Chaussadent T., Modelling of the sulphuric acid attack on differents types of cementitious materials, Cement and Concrete Research 105 (2018) 126133

Table 5: Deterioration depths obtained for CEM I, CEM III, CEM IV, CEM V cements and CAC after 1 year of acid attack at $10^{-1} \mathrm{~mol} / \mathrm{L}$.

\begin{tabular}{|c|c|c|}
\hline Materials & Dissolved calcium amount (g/L) & Weight loss (\%) \\
\hline CEM I & 90 & 37.5 \\
\hline CEM III & 80 & 33.3 \\
\hline CEM IV & 80 & 33.3 \\
\hline CEM V & 80 & 33.3 \\
\hline CAC & 35 & 14.6 \\
\hline
\end{tabular}

Table 6: Dissolved calcium contents obtained for CEM I, CEM III, CEM IV, CEM V cements, and $\mathrm{CAC}$ after 1 year of sulfuric acid attack at $10^{-1} \mathrm{~mol} / \mathrm{L}$.

\begin{tabular}{|c|c|}
\hline Materials & Corrosion rates $\left(\mathbf{m m} / \mathbf{y e a r}^{\mathbf{0 . 5}}\right)$ \\
\hline CEM I & 0.10 \\
\hline CEM III & 0.11 \\
\hline CEM IV & 0.14 \\
\hline CEM V & 0.10 \\
\hline CAC & 0.01 \\
\hline
\end{tabular}

Table 7: Corrosion rates obtained for CEM I, CEM III, CEM IV, CEM V cements, and CAC.

\section{Figure captions}

Figure 1: Concrete sewer and biodeterioration mechanisms. SRB are sulfate-reducing bacteria and SOB are sulfur-oxidizing bacteria.

Figure 2: Phase Diagram for the system $\mathrm{CaO}-\mathrm{Al}_{2} \mathrm{O}_{3}-\mathrm{SO}_{3}-\mathrm{H}_{2} \mathrm{O}$. This diagram is constituted of the simultaneous evolutions of the saturation indexes of $\mathrm{AH}_{3}\left(\beta_{\mathrm{AH} 3}\right)$ and $\mathrm{CH}\left(\beta_{\mathrm{CH}}\right)$ with the $\mathrm{H}_{2} \mathrm{SO}_{4}$ concentration $\left(\mathrm{a}_{\mathrm{H} 2 \mathrm{SO}}\right)$ in logarithmic scale.

Figure 3: Profiles of the solid phases $\left(\mathrm{CH}, \mathrm{C}_{3} \mathrm{AH}_{6}, \mathrm{AFt}, \mathrm{AH}_{3}\right.$, and $\mathrm{C} \overline{\mathbf{S}} \mathrm{H}_{2}$ (gypsum)), of the calcium to silicon ratio and of the porosity, for cementitious materials based on CEM I, CEM III, CEM IV, CEM V cements, and CAC, after 1 year of acid attack.

Figure 4: Evolution of the porosity over depth for the cementitious materials based on CEM I, CEM III, CEM IV, CEM V cements, and CAC during 1 year of sulfuric acid attack at $10^{-1} \mathrm{~mol} / \mathrm{L}$. The black circles represent the point where porosity becomes superior to the initial porosity of each cementitious material.

Figure 5: Evolution of the deterioration depth for cementitious materials based on CEM I, CEM III, CEM IV, CEM V cements, and CAC over time, during 1 year of acid attack at $10^{-1} \mathrm{~mol} / \mathrm{L}$.

Figure 6: Dissolved calcium contents over time for cementitious materials based on CEM I, CEM III, CEM IV, CEM V cements, and CAC during 1 year of sulfuric acid attack at $10^{-1} \mathrm{~mol} / \mathrm{L}$. 
Grandclerc A., Dangla P., Gueguen-Minerbe M., Chaussadent T., Modelling of the sulphuric acid attack on differents types of cementitious materials, Cement and Concrete Research 105 (2018) 126133

FIGURE 1.

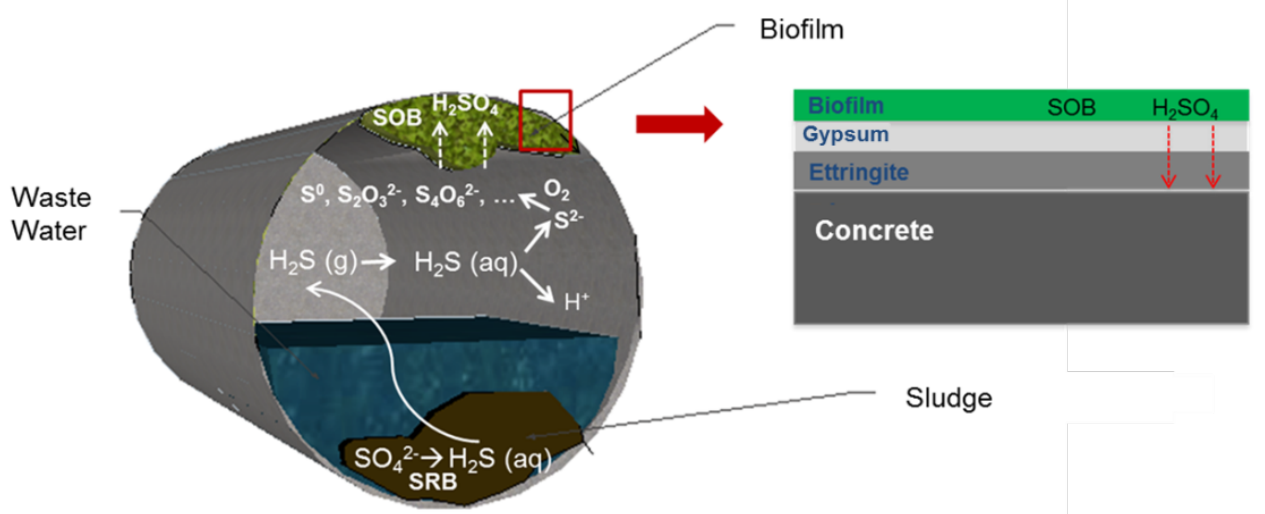

464

FIGURE 2.

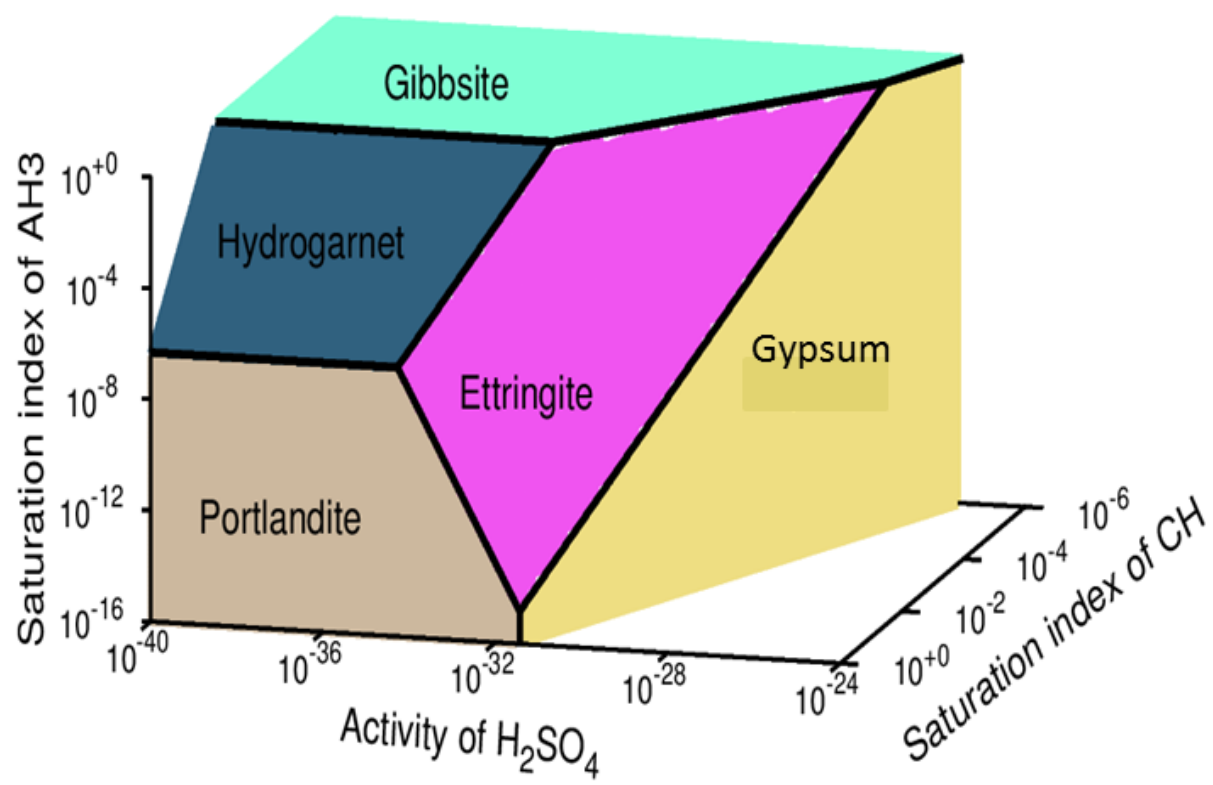

466 
Grandclerc A., Dangla P., Gueguen-Minerbe M., Chaussadent T., Modelling of the sulphuric acid attack on differents types of cementitious materials, Cement and Concrete Research 105 (2018) 126133

FIGURE 3.

CEM I

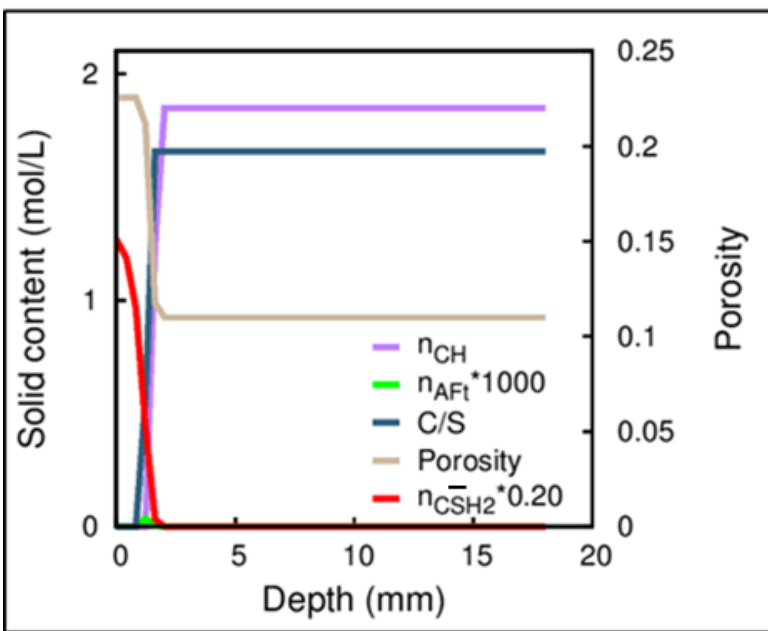

CEM IV

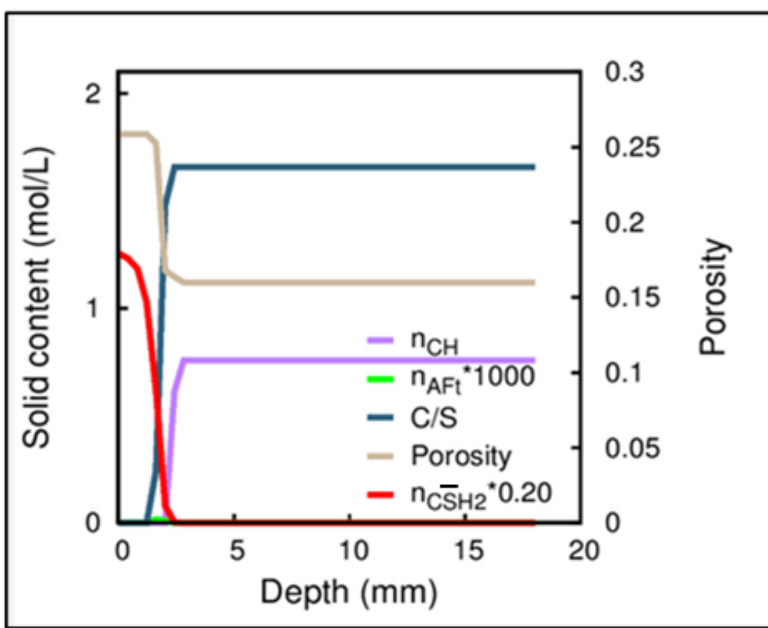

CEM III

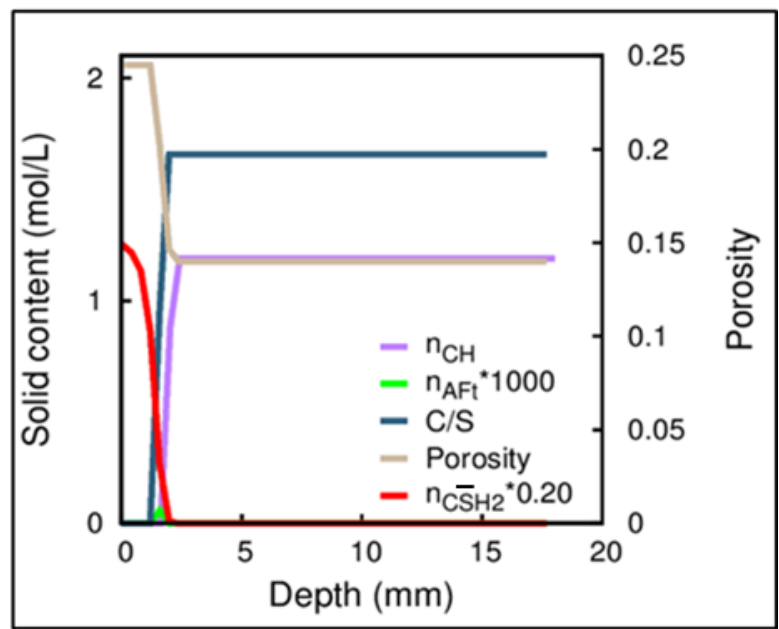

CEM V

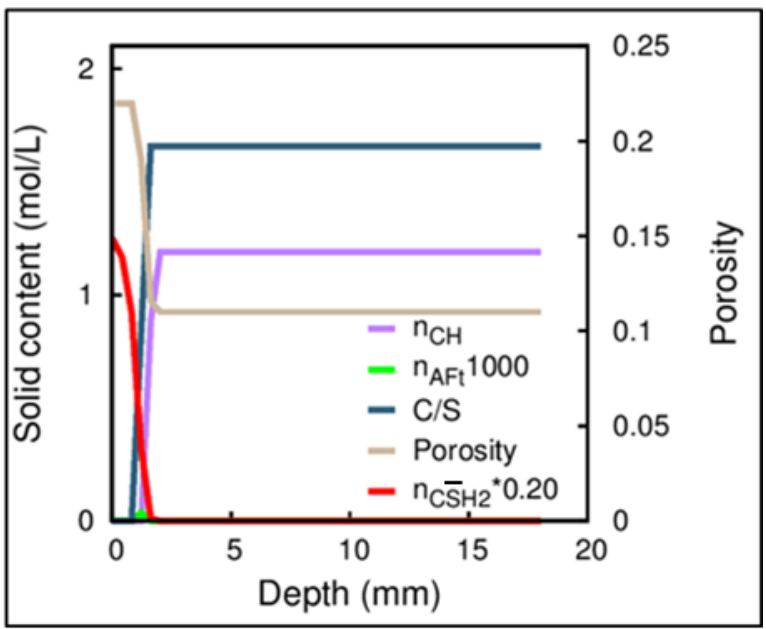

CAC

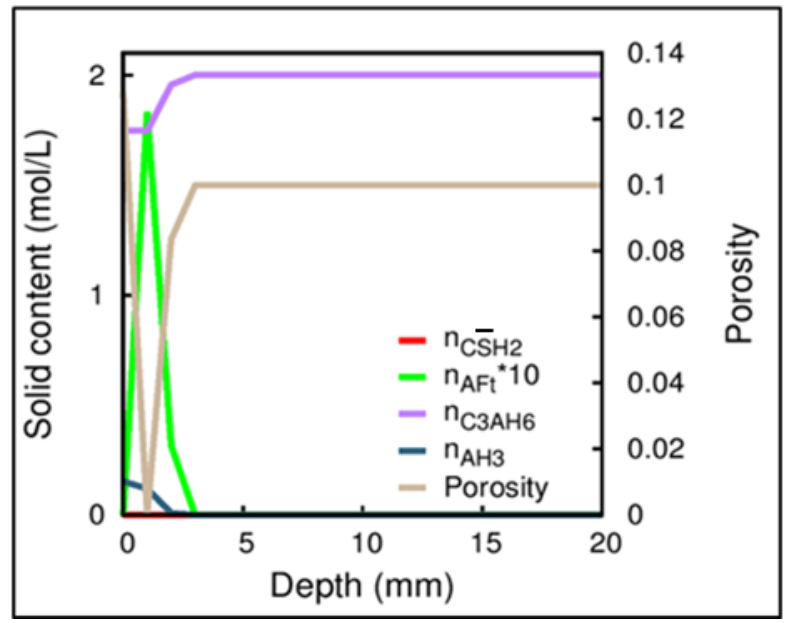


Grandclerc A., Dangla P., Gueguen-Minerbe M., Chaussadent T., Modelling of the sulphuric acid attack on differents types of cementitious materials, Cement and Concrete Research 105 (2018) 126133

472 FIGURE 4.

473

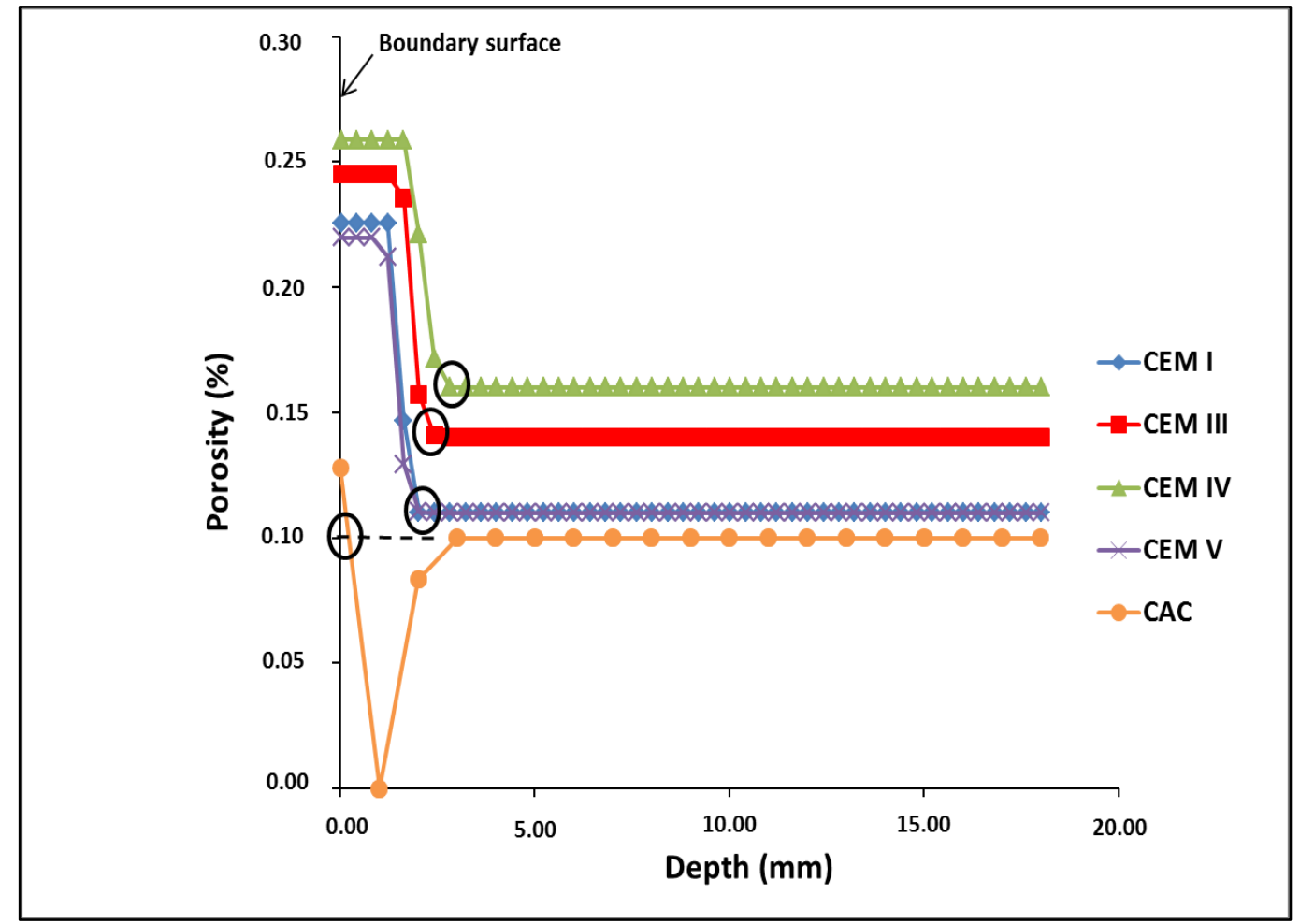

474

475

FIGURE 5.

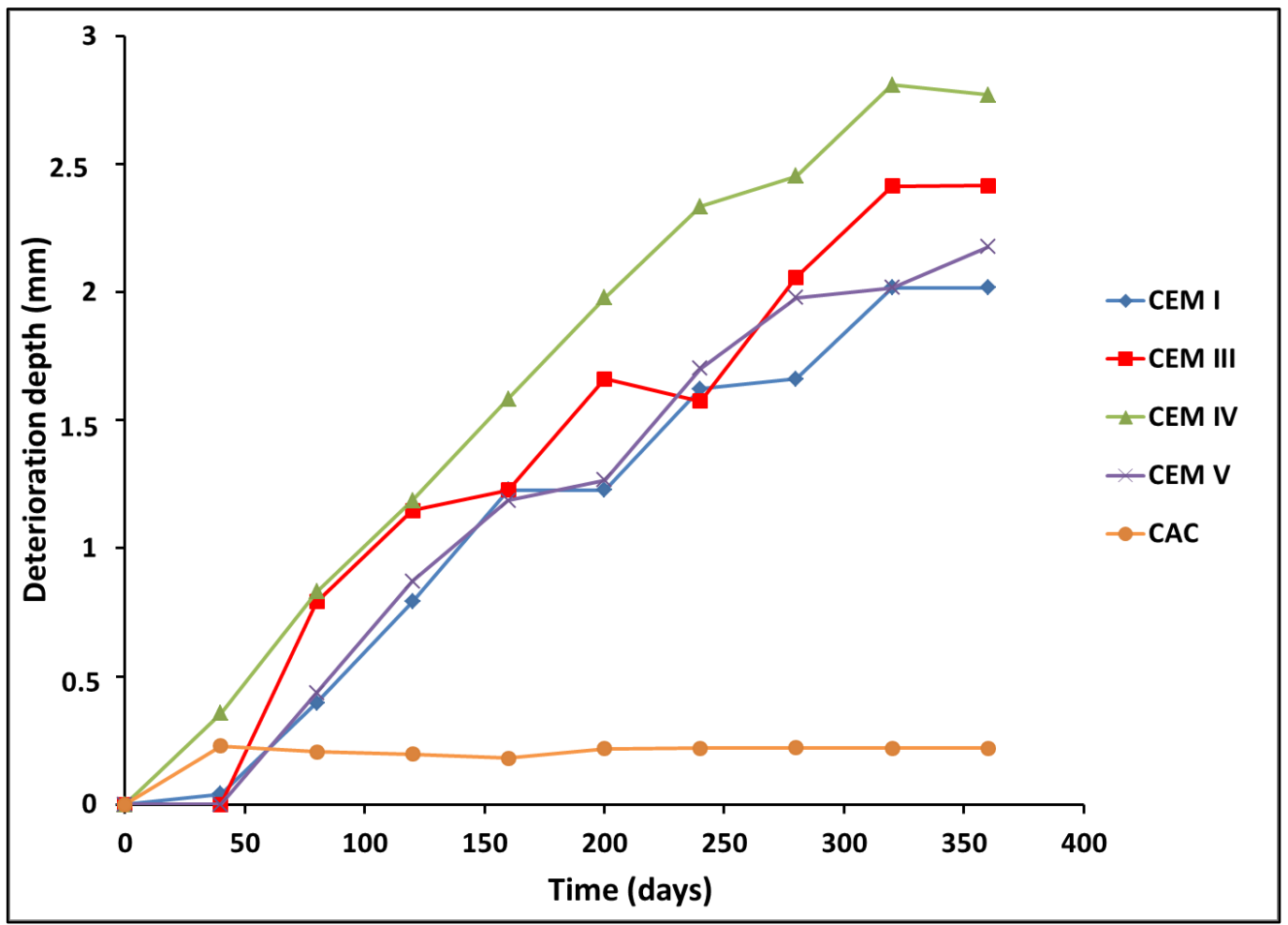


Grandclerc A., Dangla P., Gueguen-Minerbe M., Chaussadent T., Modelling of the sulphuric acid attack on differents types of cementitious materials, Cement and Concrete Research 105 (2018) 126133

FIGURE 6.

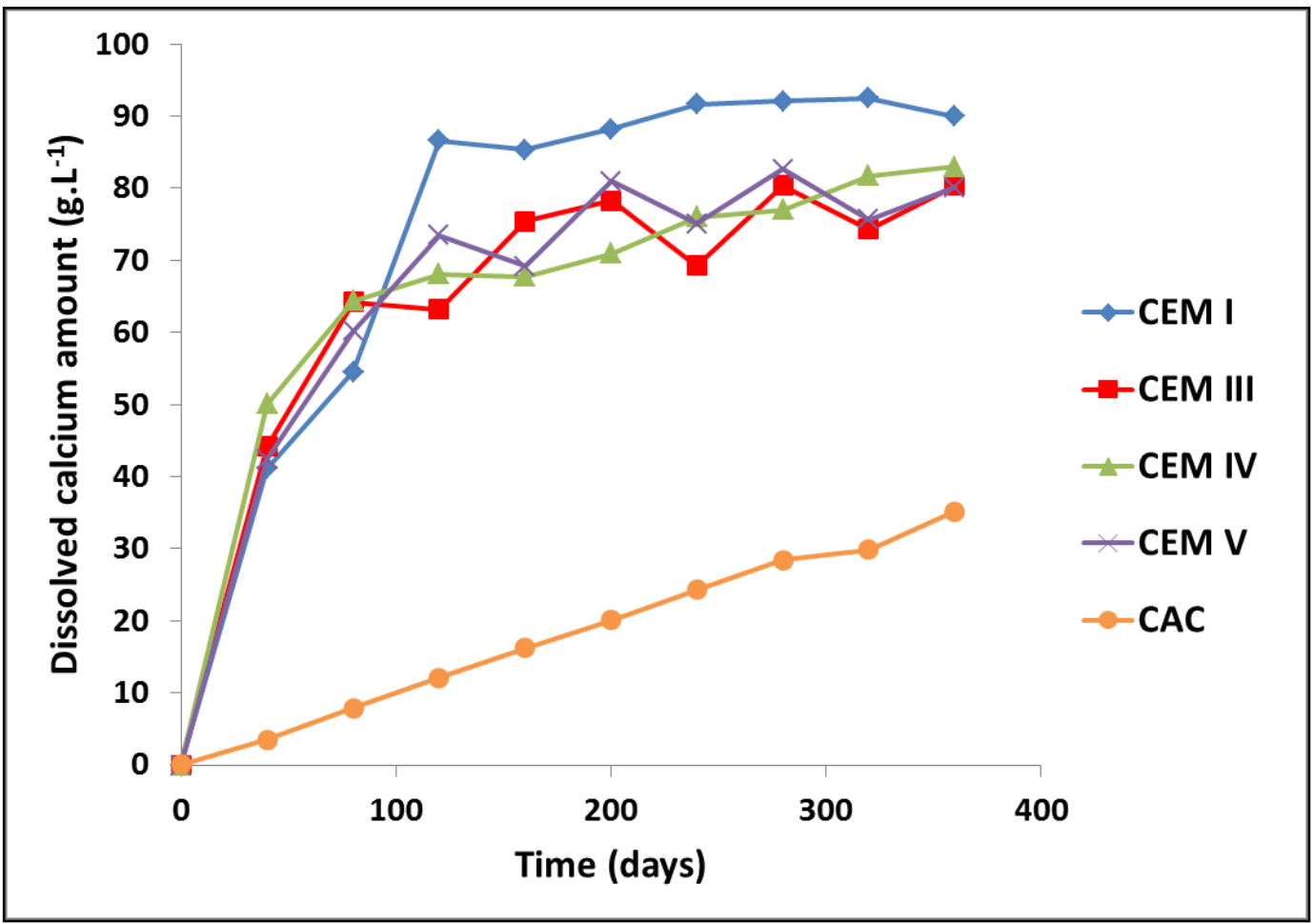

480

481

482

483

484

485

486

487

488

489

490

491 